\title{
Hate Speech dalam Masyarakat Post Truth
}

\section{(Aplikasi Hermeneutika Al-Qur'an Hassan Hanafi)}

\author{
Wiji Nurasih \\ Institut Agama Islam Negeri Purwokerto \\ Jl. A. Yani 40-A Purwokerto 53126 \\ E-mail: wijin2409@gmail.com
}

\begin{abstract}
:
Hate speech is increasingly becoming a serious threat to the unity of the Republic of Indonesia which is very diverse. The characteristics of people in the post-truth era that are more influenced by personal opinion than reality cause their emotions and sentiments to be easily ignited which results in intolerance and strife. How bad is the Qur'an which in some verses forbids the utterance of hate speech, one of which is through verse 1 of Surah alHumazah, which strongly denounces and cursing. This study aims to analyze the behavior of hate speech through thematic studies of the Qur'an by applying the thematic interpretation method offered by Hasan Hanafi. The reading of the text according to Hanafi needs to go through three phases namely historical, eidetic and practical criticism. From this research, it was obtained that historically the Al-Qur'an was an authentic book since it was revealed until now, its truth was believed and used as a guide to Muslim life. Through eidetic criticism, the Qur'an reveals the prohibition of hate speech even condemns it. To overcome this, synergy efforts between the government, consumers and information producers must be done in combating hate speech by adapting values in the Qur'an such as the tabayyun attitude for the community, the principles of honesty, accuracy, fairness, and others for information producers.
\end{abstract}

Keyword: Al-Qur'an, Hate speech, and Post Truth.

\begin{abstract}
Abstrak:
Ujaran kebencian semakin menjadi ancaman serius terhadap persatuan NKRI yang sangat majemuk. Karakteristik masyarakat di era post truth yang lebih terpengaruh pada opini personal daripada realitas menyebabkan emosi dan sentimennya mudah tersulut yang berdampak pada intoleransi dan perselisihan. Betapa buruknya Al-Qur'an yang dalam beberapa ayat melarang perilaku ujaran kebencian salah satunya melalui ayat 1 surat alHumazah melarang keras mencela dan mengumpat. Penelitian ini bertujuan menganalisis perilaku ujaran kebencian melalui kajian tematik Al-Qur'an dengan mengaplikasikan metode penafsiran tematik yang ditawarkan oleh Hasan Hanafi. Pembacaan teks menurut Hanafi perlu melalui tiga fase yakni kritik historis, eidetik dan kritik praktis. Dari penelitian ini diperoleh hasil bahwa secara historis Al-Qur'an merupakan kitab yang otentik sejak diturunkan hingga saat ini, diyakini kebenarannya dan dijadikan pedoman hidup muslim. Melalui kritik eidetik, Al-Qur'an mengungkapkan pelarangan terhadap perilaku ujaran kebencian bahkan mengecamnya. Untuk mengatasi
\end{abstract}


hal tersebut upaya bersinergi antara pemerintah, konsumen dan produsen informasi harus dilakukan dalam memerangi perilaku ujaran kebencian dengan mengadaptasi nilai-nilai dalam Al-Qur'an seperti sikap tabayyun bagi masyarakat, prinsip kejujuran, akurasi, keadilan dan lain-lain bagi produsen informasi.

\section{Kata Kunci: Al-Qur’an, Ujaran Kebencian, dan Post Truth.}

\section{A. Pendahuluan}

$\mathrm{H}$ ate speech atau ujaran kebencian menjadi fenomena yang semakin nyata dalam konteks masyarakat post truth. Keberadaanya semakin berkembang luas sebab adanya dorongan dari kemajuan teknologi digital yang memungkinkan setiap orang secara aktif memproduksi suatu informasi, melayangkan pendaapat mereka dan merespon setiap hal yang ada dalam dunia maya. Hingga saat ini telah tercatat banyak kasus ujaran kebencian yang dilayangkan melalui media sosial yang berbasis online yang pelakunya berasal dari berbagai latar belakang bukan hanya politikus namun juga pengajar, karyawan, pemuka agama dan lain-lain. Hal ini merupakan tantangan bagi persatuan dan kesatuan bangsa karena dengan berkembangnya hate speech dapat menimbulkan kesenjangan dalam masyarakat, menyebabkan perselisihan dan perpecahan. Begitu pula dengan karakteristik masyarakat post truth yang lebih mempercayai opini personal daripada fakta menjadikannya mudah tersulut sentimennya ketika menerima suatu informasi yang mengandung ujaran kebencian.

Keberadaan ujaran kebencian seringkali saling terikat dengan hoax (berita bohong) yang secara sengaja dibuat untuk semakin menyudutkan objek ujaran kebencian. Hal ini memerlukan perhatian serius agar negara Indonesia yang penuh dengan kemajemukan dapat terselamatkan kebhinekaannya. Untuk itu berbagai upaya telah dilakukan contohnya dengan ditetapkannya berbagai peraturan tentang ujaran kebencian. Al-Qur'an sebagai kitab suci yang shalih li kulli zaman wa makan pun mampu merespon fenomena ini melalui beberapa ayatnya. Dalam penelitian ini akan dilakukan kajian terhadap beberapa ayat yang berkaitan dengan ujaran kebencian antara lain surat al-Hujurat ayat 11, surat al-Humazah ayat 1, dan surat al-Qalam ayat 10 . Ayat-ayat tersebut akan dianalisis berdasarkan hermeneutika yang digagas oleh Hassan Hanafi. Melalui hermeneutika ini, suatu teks akan dipahami maknanya dalam konteks saat ini tanpa mengabaikan konteks masa lalu dan menjadikannya tidak sebatas sebagai wacana namun mampu mengantarkan pada aksi perubahan sosial melalui kesadaran praktis yang dibangun darinya. (Nugroho 2016, 194) Berdasarkan latar belakang tersebut, diharapkan tulisan ini tidak hanya mampu mendobrak kesadaran namun juga 
bisa memberi solusi yang diadaptasi dari nilai-nilai Al-Qur'an untuk menanggulangi dan mengatasi persoalan masyarakat era digital.

\section{B. Masyarakat Post Truth}

Post truth atau "pasca kebenaran" menurut Nezar Patria merupakan kondisi di mana suatu informasi bohong diproduksi dan disebarluaskan untuk memunculkan sentimen, mengelaborasi suatu kejadian agar tampak nyata dan menyulut emosi publik dengan memanfaatkan media digital yang aksesnya sangat cepat. (Parani 2018, 60) Di era ini kebenaran merupakan persoalan persepsi sedangkan fakta kurang berpengaruh dalam membangun opini publik. Masyarakat dengan mudah mempercayai suatu informasi sepanjang hal itu sesuai dengan apa yang diyakininya meskipun secara fakta tidak dapat dipertanggungjawabkan. Dengan kata lain yang dicari adalah pembenaran bukan kebenaran. Keadaan tersebut kemudian ada yang memanfaatkannya untuk mempengaruhi pikiran masyarakat. Hal demikian sangat terasa terutama di tahun 2019 yang menjadi kontes perpolitikan di Indonesia. Berbagai ujaran kebencian dilemparkan kepada lawan politik untuk semakin menarik simpati pendukung.

Ujaran kebencian dapat dimaknai sebagai pernyataan permusuhan. Berdasarkan Kovenan Internasional Sipil Politik pasal 20 ujaran kebencian dapat diartikan sebagai propaganda untuk perang dan segala yang menganjurkan kebencian atas kebangsaan, ras atau agama yang merupakan hasutan untuk melakukan deskriminasi, permusuhan atau kekerasan. (Anam 2015, 344) Adanya rasa permusuhan ini dapat ditimbulkan karena adanya fanatisme yang berlebihan baik terhaap agama, politik ormas dan lainlain. ${ }^{1}$ Keberadaan ujaran kebencian mampu menimbulkan intoleransi dalam masyarakat dan disintegrasi. Maka dari itu, berbagai negara termasuk Indonesia menerapkan peratutran berkaitan hal itu salah satunya adalah pasal 156 KUHP yang melarang menyatakan permusuhan, kebencian dan merendahkan kelompok lain. Suatu ungkapan dapat dikatakan sebagai ujaran kebencian jika hal tersebut memenuhi unsur-unsur antara yaitu segala perbuatan yang secara langsung maupun tidak (lisan atau tulisan) yang bertujuan untuk orang lain melakukan perbuatan yang disarankan dalam ungkapan tersebut. Di samping itu ujaran kebencian ini juga memuat deskriminasi (pembedaan atau pengecualian yang menyebabkan orang lain tidak memperoleh hak asasinya), kekerasan (perbuatan yang menimbulkan penderitaan fisik maupun psikologi), bersifat menghasut (mendorong orang untuk mendeskriminasi, memusuhi dan melakukan kekerasan) dengan menggunakan sarana tertentu sehingga mampu menciptakan konflik sosial. (Asphianto 2017, 32-33)

\footnotetext{
${ }^{1}$ Kedaulatan Rakyat, 2019, 22 Mei. Pendidikan Agama Islam di Era Post-Truth
} 


\section{Metode Tematik Dan Hermeneutika Hassan Hanafi}

Penelitian ini akan mengkaji ujaran kebencian dari sudut pandang Al-Qur'an. Untuk itu metode yang digunakan adalah metode penafsiran tematik atau maudu'i. Dengan metode ini penelitian dilakukan dengan mengumpulkan dan memahami ayat yang berkaitan dengan tema yang dikaji kemudian merumuskannya menjadi sebuah konsep yang utuh, sistematik dan holistoic. Metode ini didasarkan paa asumsi bahwa ayat-ayat dalam Al-Qur'an saling menjelaskan satu dengan yang lainnya (Al-Qur'an yufassiru ba'dluhu ba'dlan). Tafsir tematik ini memiliki keunggulan jika dibandingkan dengan metode tahlili yang mengupas ayat-ayat secara parsial meskipun mampu mengungkapkan segala aspek mengenai suatu ayat. Namun menurut Muhammad Abduh tafsir tahlili dikategorikan sebagai tafsir yang kering dan menjauhkan dari petunjuk Allah SWT. Sedangkan kelebihan tafsir tematik menurut Fazlur Rahman adalah mampu mengantarkan pada pemahaman yang komprehensif dan menyeluruh dari Al-Qur'an. Metode ini juga mampu mengontrol bias-bias ideologi yang dipaksakan dalam proses penafsiran Al-Qur'an karena ketepatan penafsiran dapat dilacak melalui pertimbangan struktur logis dan relasi ayat-ayat satu tema yang dijadikan objek kajian. Metode tematik yang akan digunakan dalam penelitian ini adalah tematik konseptual yang meriset konsep-konsep tertentu yang tidak secara eksplisit disebutkan dalam Al-Qur'an namun memuat ide tentang konsep itu dari segi substansialnya. (Mustaqim 2015, 5762)

Salah satu tokoh yang mendukung tafsir ini adalah Hassan Hanafi. Ia merupakan salah satu penggagas hermeneutika kritis emansipatoris yang memerlukan tiga fase untuk analisis dalam menginterpretasi suatu teks yakni kritik hiostoris, kritik eiditik dan kritik praktis. Kritik historis berguna untuk memastikan validitas atau keotentikan suatu teks. Kritik eidetis berfungsi untuk menginterpretasi teks yang didalamnya ditentukan syarat antara lain penafsir harus melepaskan diri dari pemahaman yang sudah ada dan mengerti setiap fase dalam teks. Dalam kritik eidetik ada beberapa langkah yakni analisa bahasa, analisa konteks sejarah yang fokus mengkaji latar belakang adanya suatu teks. Sedangkan, kritik praktis merupakan membuktikan sejauh mana hasil intepretasi mampu memotivasi untuk melakukan suatu transformasi.

\section{MembaCa Ayat-Ayat Hate SPEeCh Dengan Hermeneutika HaSan Hanafi}

\section{Kritik Historis}

Analisis hermeneutika Hassan Hanafi yang telah dijelaskan diatas terdiri dari kritik historis, kritik eidetik dan kritik praktis akan dijadikan acuan dalam menggali ayat-ayat yang akan dikaji. Langkah awal yakni kritik historis yang berfungsi untuk 
memastikan keaslian teks. Dalam hal ini Al-Qur'an dari segi teksnya sudah berada di titik final yang tidak berubah sejak diturunkan hingga saat ini. Hal ini sudah diyakini oleh setiap umat muslim bahwa Al-Qur'an saat ini memang otentik. Meskipun banyak sarjana Barat mendebat dan bersikap skeptis terhadap keasliannya namun jaminan keaslian Al-Qur'an lebih kuat baik dilihat dari teksnya maupun sisi kesejarahan.

Melalui surat al-Hijr ayat 9, Al-Qur'an telah dinyatakan terjamin keasliannya karena ia dipelihara langsung oleh Allah SWT. Al-Qur'an juga sangat unik dari segi penggunaan kata. Huruf hija'iyah dalam permulaan beberapa surat mampu menjamin keutuhan Al-Qur'an (tidak berkurang atau bertambah) sejak diterimanya oleh Nabi Muhammad SAW. Jumlah huruf-huruf tersebut dalam suatu surat akan habis dibagi 19 (sejumlah huruf yang terdapat dalam lafadz basmalah) contohnya adalah huruf qaf yang merupakan permulaan dari surat Qaf terulang sebanyak 57 kali atau 19 x 3. Begitu pula dengan surat-surat lainnya yang dengan ini menandakan Al-Qur'an tetap utuh sejak diturunkan hingga kini. Sedangkan dari segi kesejarahan ada beberapa faktor yang bisa membuktikan keasliannya antara lain Al-Qur'an diturunkan dalam masyarakat Arab yang tidak bisa baca tulis sehingga hafalan orang Arab yang sangat kuat diandalkan untuk menjaga Al-Qur'an. Kedua, masyarakat Arab dikenal dengan kesederhanaan hidup sehingga memiliki banyak waktu untuk menambah ketajaman hafalan dan pikiran. Ketiga, mereka memiliki kegandrungan terhadap susastra. Keempat, Al-Qur'an memiliki keindahan bahasa yang menjadikannya menarik bahkan bagi kaum musyrik. Kelima, Al-Qur'an dan Rasul memerintahkan untuk memperbanyak membaca dan mempelajari Al-Qur'an. Keenam, Rasul memerintahkan untuk selalu bersikap hati-hati dalam menyampaikan berita terlebih jika itu adalah firman Allah SWT. Ketika dilakukan penulisan Al-Qur'an pun, kehati-hatian yang sangat tinggi diterapkan yakni naskah yang disalin harus sesuai dengan hafalan para sahabat serta ditulis atas perintah dan dilakukan dihadapan Nabi. Atas hal itu maka keotentikan Al-Qur'an tidak bisa diragukan lagi. (Shihab 1995, 21-25)

\section{Kritik Eidetik}

Setelah legalitas dan validitas Al-Qur'an terbukti maka langkah senjutnya adalah melakukan kritik eidetik. Dalam fase kedua ini diperlukan kesadaran eidetis. Kesadaran ini menurut Hassan Hanafi merupakan bagian terpenting dalam proses interpretasi karena dalam tahap ini akan diketahui sejauh mana kemampuan merepresentasikan pemahaman. (Hanafi 2003, 125) Dalam Al-Qur'an terdapat ayat yang dapat dikaitkan dengan ujaran kebencian antara lain dalam QS. al-Hujurat: 11, QS. al-Humazah: 1, dan QS. al-Qalam: 10.

\section{a. QS. Al-Hujurat ayat 11}




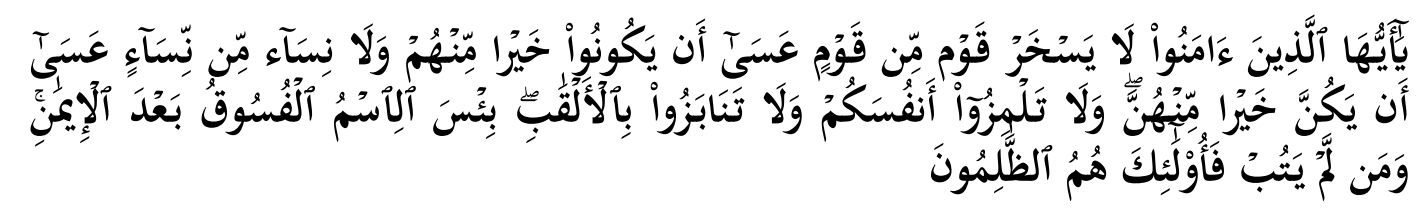

"Hai orang-orang yang beriman, janganlah sekumpulan orang laki-laki merendahkan kumpulan yang lain, boleh jadi yang ditertawakan itu lebih baik dari mereka. Dan jangan pula sekumpulan perempuan merendahkan kumpulan lainnya, boleh jadi yang direndahkan itu lebih baik. Dan janganlah suka mencela dirimu sendiri dan jangan memanggil dengan gelaran yang mengandung ejekan. Seburuk-buruk panggilan adalah (panggilan) yang buruk sesudah iman dan barangsiapa yang tidak bertobat, maka mereka itulah orang-orang yang zalim"

Dalam ayat tersebut as-sukhriyah berarti mengolok-olok, menyebut aib, dan kekurangan-kekurangan orang lain yang dapat menimbulkan tawa. Sedangkan kata attanabuz berarti saling mengejek dan memanggil dengan gelar yang tidak disukai sesorang. Sedangkan al-ismu bermakna nama dan kemasyhuran. Di samping itu dalam ayat ini disebutkan pula kata anfusakum. Menurut al-Maraghi, kata tersebut berisi peringatan agar seorang yang berakal tidak mencela dirinya sendiri. Maka tidak pula dia mencela orang lain, sebab orang lain adalah sebagaimana dirinya sendiri. Ini sesuai dengan hadis yang mengibaratkan mukmin sama halnya dengan satu tubuh, apabila satu anggota tubuh sakit maka anggota tubuh lain merasakan hal yang sama. (Al-Maraghi 1993, 220-21)

Dalam konteks masa kini di mana perbedaan contohnya dalam internal agama mendorong seseorang untuk menyatakan kebencian dengan menyertakan keburukankeburukan pihak yang dibenci serta memancing adanya permusuhan yang diunggah melalui media tidak diperbolehkan karena ia mengandung unsur hinaan, pencemaran nama baik serta perbuatan tidak menyenangkan yang dalam ayat diatas disebut dengan istilah as-sukhriyah dan at-tanabuz. Berdasarkan riwayat, ayat ini diturunkan berkaitan dengan orang Tamim yang mengejek orang fakir dari kalangan sahabat Nabi sebab keadaan para sahabat yang terlihat compang-camping. Di sini terlihat bahwa seorang yang memiliki materi akan merasa dirinya lebih baik yang lantas mendorongnya untuk mencaci orang lain yang memiliki tingkat sosial yang rendah. Ini bersesuaian dengan karakteristik masyarakat jahiliyyah yang sangat gandrung dengan kekayaan. Padahal dalam ayat ini ditegaskan bahwa boleh jadi yang direndahkan justru memiliki kelebihan. Ini mengingatkan bahwa setiap manusia terlahir dengan kekurangan dan kelebihannya masing masing. Satu kelebihan seharusnya tidak lantas menjadikan orang menyoimbongkan diri dannmerendahkan orang lain karena di sisi lain tentu terdapat kekurangan dalam diri setiap orang. Adanya kekurangan dan kelebihan yang berbedabeda diantara manusia hendaknya dimaknai sebagai saling melengkapi. Jika menurut keterangan tersebut maka seorang yang kaya hendaknya menjadi penolong yang lemah bukan mencacinya. Hal yang serupa dapat diterapkan dalam berbagai lini kehidupan 
seperti dalam masyarakat yang penuh kemajemukan. Sifat heterogen dalam masyarakat tidak dijadikan untuk saling membenci namun untuk memperkaya pengetahuan, saling mengenal dan lain-lain.

Riwayat lain juga menyebutkan bahwa turunnya ayat ini berkenaan dengan Shafiyah yang mengadu kepada Rasulullah SAW perihal perkataan suatu kaum wanita yang menuduhnya sebagai wanita Yahudi dan anak perempuan orang Yahudi. Maka Rasul pun berkata "Tidakkah kamu katakan ayahku Harun, pamanku Musa, dan suamiku Muhammad." Dari riwayat ini Rasul mengajarkan bagaimana menyikapi seseorang yang mencela yaitu dengan melakukan pembenaran jika pencela salah dalam ucapannya.

Ayat ini berisi peringatan halus bagi seorang mukmin untuk tidak memperolok mukmin lainnya karena yang diperolok terkadang lebih baik di sisi Allah daripada yang memperolok. Orang yang beriman akan selalu memeriksa kekurangan yang ada pada dirinya sedangkan perbuatan yang suka menilai kekurangan orang lain merupakan perbuatan orang yang tidak beriman sebagai penyebab seseorang lupa akan kekurangan sendiri. (Hamka 2003, 6828) Sejalan dengan hal ini sebuah hadis dari Abu Hurairah menyatakan bahwa Rasulullah SAW bersabda:

Seorang muslim adalah saudara bagi muslim yang lainnya. Ia tidak boleh menghinanya, membohonginya, dan merendahkannya. Setiap muslim haram atas muslim lainnya (untuk diganggu) harga dirinya, hartanya, dan darahnya. Takwa itu di sini (dalam hati). Seseorang sudah cukup dianggap buruk jika ia menghina saudaranya sesama muslim. (Najati 2008, 64)

Perintah untuk tidak menghina, mencaci dan mecela terhadap kaum muslim tidak lantas menyebabkan muslim boleh mencela orang yang berbeda keyakinan. Karena Rasul mengajak untuk tidak hanya menyayangi muslim saja namun juga seluruh makhluk ciptaan Allah SWT yang tentu tercakup didalamnya setiap manusia (tanpa pandang keyakinan) juga hewan, tumbuhan dan lain sebagainya. Perdamaian merupakan konsep universal yang berlaku bagi mukmin saja melainkan penganut agama lain. Adanya perbedaan kepercayaan atau pandangan dalam beberapa hal seringkali menimbulkan antipati terhadap yang berbeda. Keadaan ini pun dapat memicu pertentangan dan ujaran kebencian. Maka dari itu, perlu ditanamkan dalam kesadaran setiap manusia bahwa setiap manusia adalah warga dunia sehingga manusia yang bertugas sebagai khalifah fil ardh memiliki tanggung jawab untuk menjaga perdamaian di antara sesama manusia di seluruh dunia.

\section{b. QS. Al-Humazah ayat 1}

"Kecelakaanlah bagi setiap pengumpat lagi pencela"

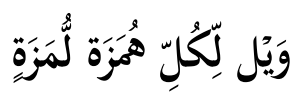


Jika dalam surat al-Hujurat diberikan peringatan yang halus untuk tidak mencela atau memperolok orang lain maka dalam ayat ini disebutkan kecaman keras bagi para pencela dan pengumpat. Dari segi bahasa, kata wail merupakan penggambaran tentang kesedihan, kenistaan dan kecelakaan kata ini juga bermakna mendoakan seseorang untuk mendapatkan keadaan buruk tersebut baik yang sedang berlangsung maupun di masa yang akan datang. Maka dari itu, kata ini menerangkan acaman keras bagi pencela dan pengumpat. Kemudian kata al-humazah memiliki pengertian mendorong orang lain dengan ucapan atau menggunjing, mengumpat dan mencela tidak dihadapan orang yang bersangkutan. Kata yang semakna adalah ghibah. Dalam suatu hadis dijelaskan bahwa ghibah adalah membicarakan sesuatu tentang orang lain apa yang tidak disenanginya meskipun hal tersebut sesuai dengan fakta. Jika keburukan tersebut dalam kenyataannya tidak benar maka hal itu merupakan kebohongan besar. Adanya ujaran kebencian yang beredar dalam masyarakat seringkali tidak terlepas dari hoax atau berita bohong yang dilakukan untuk semakin menyudutkan objek ujaran kebencian. Kemudian, kata lumazah berarti ejekan yang menguindang tawa baik menggunakan isyarat, ucapan, secara langsung maupun tidak langsung.

Diturunkannya ayat ini menurut al- Kalby berkaitan dengan Al-Akhnas ibnu Syuraiq yang sangat gemar memperolok dan mengumpat orang lain terutama Rasulullah. Kemudian berdasar riwayat Muqatil, ini berkenaan dengan Walid ibnu Mughirah yang berani mengumpat Nabi dari belakang, di samping atau mencaci secara terus terang.

Al-Qur'an memandang betapa tercelanya perbuatan mengumpat dan mencela sehingga dalam ayat ini disebutkan kata kulli mengisyaratkan setiap orang mendapat ancaman keras apabila melakukan perbuatan tersebut dalam berbagai bentuknya termasuk mengedarkan tulisan, gambar, audio dan video yang memuat celaan dan umpatan. Terkait hal ini ada beberapa pengecualian sehingga menyebutkan kejelekan orang lain diperbolehkan dengan syarat-syarat dibawah ini:

1) Untuk mengadukan tindakan penganiayaan

2) Agar memperoleh bantuan untuk tersingkirkan dari keburukan

3) Menyebutkan kejelekan utuk meminta fatwa keagamaan

4) Membicarakan keburukan seseorang yang tidak malu atau secara terangterangan melakukannya

5) Menyebutkan keburukan seseorang untuk menghindarikan orang lain dari keburukan tersebut

6) Memeberi identifikasi kepada orang tertentu yang orang tersebut tidak dikenali tanpa ciri tersebut (Shihab 2003b, 513)

\section{c. QS. Al-Qalam ayat 11}


"Yang banyak mencela, yang kian ke mari menghambur fitnah"

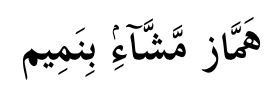

Namim merupakan bentuk mashdar dari namimah yakni penyampaian berita yang menyakitkan hati pendengar dan menyebabkan permusuhan antar manusia. Ayat ini turun berkenaan dengan keinginan orang kafir yang mengharapkan Nabi bersikap lunak kepada orang kafir dengan tidak melarang mereka menyembah berhala atau mengizinkan mereka berdurhaka. Disini ditegaskan bahwa Nabi tidak diperbolehkan mengikuti kehendak mereka dan diperkuat dengan sifat-sifat tercela orang kafir yang harus dihindari yaitu yang suka mencela dan menyebarkan fitnah. (Shihab 2003a, 384) Perbuatan tersebut merupakan perangai sebagian orang yang mendustakan kebanaran. Seseorang dengan karakter demikian melihat yang lain hanya dari sisi buruknya saja disebabkan hatinya penuh dengan kebencian dan dengki.

\section{E. Kritik Praktis (Solusi QUR'ANi)}

Dari uraian di atas tampak bahwa bukan saja peraturan formal yang melarang tindakan ujaran kebencian namun juga Al-Qur'an yang menjadi pedoman umat muslim di setiap zaman dan tempat. Oleh karena itu keberadaan ujaran kebencian harus ditekan dan dicarikan solusi yang mampu mencegah seseorang untuk melakukan hal tersebut serta menghindarkan masyarakat luas dari ikut terhasut oleh ujaran kebencian yang ada. Dalam kasus ujaran kebencian setidaknya ada tiga elemen yang perlu mengupayakan pencegahan dan resistensi terhadap ujaran kebencian yang tersebar dunia maya. Ketiga elemen itu adalah masyarakat sebagai konsumen informasi, penyampai informasi dan pemerintah sebagai pihak yang berwenang dalam mengatur urusan yang berkaitan dengan kemaslahatan rakyat. Maka dari itu upaya bersinergi dari ketiga komponen tersebut harus dilakukan untuk meminimalisir dampak buruk yang diakibatkan dari perilaku ujaran kebencian.

\section{Solusi Bagi Masyarakat}

Surat al-Hujurat ayat 6 artinya "Hai orang-orang yang beriman, jika datang kepadamu orang fasik membawa suatu berita, maka periksalah dengan teliti agar kamu tidak menimpakan suatu musibah kepada suatu kaum tanpa mengetahui keadaannya yang menyebabkan kamu menyesal atas perbuatanmu itu." Ayat ini mengamanahkan agar masyarakat tidak mempercayai begitu saja suatu informasi. Hendaknya selalu mengecek kebenarannya bukan sebaliknya yaitu mempercayai begitu saja selama sejalan dengan keyakinan pribadi. Ayat ini sesuai dengan semangat literasi media yang perlu ditanamkan pada setiap orang. Untuk itu maka perlu dilakukan sosialisasi bagaimana bijak dalam menggunakan media dan menerima suatu informasi. 


\section{Solusi Bagi Produsen Informasi}

Untuk produsen informasi baik itu kelompok maupun setiap orang yang membuat dan menyampaikan sesuatu hendaknya mematuhi prinsip-prinsip komunikasi yang selaras dengan ajaran Al-Qur'an antara lain kejujuran (fairness). Ini bersesuaian dengan hadis yang menyebutkan bahwa "Hendaklah kalian senantiasa jujur, karena kejujuran akan membawa pada kebaikan dan kebaikan akan membawa ke surga. Dan ketika seseorang senantiasa berlaku jujur dan berusaha keras untuk jujur, sehingga ia tercatat di sisi Allah sebagai orang yang benar-benar jujur." Prinsip kedua yaitu akurasi informasi yang disampaikan. Ini bersesuaian dengan surat al-Nur ayat 11-12. Prinsip ketiga yaitu bebas bertanggung jawab. Maksudnya informasi apapun boleh disampaikan sejauh yang menyampaikan bersedia bertanggung jawab atas hal itu. Prinsip keempat yaitu adil dan tidak memihak. Terakhir, informasi yang disampaikan hendaknya mampu memberikan kritik yang membangun. Media sosial yang menjadi tempat persaingan dan memperoleh keuntungan material seyogyanya tidak menjadikan produsen informasi mengabaikan prinsip-prinsip Islami tersebut. (RI 2019, 286-97)

\section{Solusi Bagi Pemerintah}

Pemerintah sebagai lembaga yang memiliki kewanangan harus terus gencar dan meningkatkan kemampuan dalam menemukan serta menindak pelaku ujaran kebencian terutama di ruang media sosial yang banjir dengan informasi sehingga potensi tidak teridentifikasinya suatu ujaran kebencian yang mampu menghasut masyarakat dan memunculkan konflik itu besar. Langkah berikutnya adalah memberi hukuman tegas bagi pelaku tersebut sehingga mampu memberi efek jera bukan hanya bagi pelaku namun juga masyarakat secara luas sehingga meningkatkan kehati-hatian ketika bermaksud menyebarkan informasi tertentu.

\section{F. Simpulan}

Ujaran kebencian yang akhir-akhir ini banyak bertebaran di media sosial merupakan perbuatan yang melanggar hukum formal. Begitu pula jika dilihat dari perspektif Al-Qur'an. Ujaran kebencian sama dengan tindakan mencela, merendahkan seorang atau sekelompok orang, pencemaran nama baik, mencaci penghinaan dan lainlain. Surat al-Hujurat ayat 11 , surat al-Humazah ayat 1 dan surat al-Qalam ayat 11 termasuk ayat-ayat yang menyebutkan pelarangan beserta ancaman yang akan diperoleh oleh seorang yang melakukan perbuatan tersebut. Maka dari itu, telah jelas bahwa perbuatan ujaran kebencian harus dihindari agar tidak menimbulkan permasalahan, perselisihan dan permusuhan dalam masyarakat. Untuk itu upaya bersinergi harus dilakukan oleh masyarakat konsumen informasi, produsen informasi dan pemerintah 
untuk memerangi perilaku tersebut. Untuk masyarakat perlu ditanamkan kesadaran, kecerdasan dan literasi media. Bagi konsumen informasi harus menerapkan prinsipprinsip komunikasi yang Islami. Selanjutnya pemerintah bertugas mengontrol peredaran informasi dan menindak secara tegas pelaku yang menyebarkan ujaran kebencian melalui media sosial.

\section{G. Daftar Pustaka}

Al-Maraghi, Ahmad Mustofa. 1993. Tafsir Al-Maraghi. Semarang: Toha Putra.

Anam, M Choirul dan Muhammad Hafidz. 2015. "Surat Edaran Kapolri Tentang Penanganan Ujaran Kebencian (Hate Speech) Dalam Kerangka Hak Asasi Manusia.” Keamanan Nasional 1(3).

Asphianto, Aan. 2017. "Ujaran Kebencian Dalam Sudut Pandang Hukum Positif Dan Islam.” Al-Risalah 7(1).

Hamka. 2003. Tafsir Al-Azhar. 9th ed. Singapura: Kerjaya Printing Industries Pte Ltd.

Hanafi, Hassan. 2003. Islamologi 1: Dari Teologi Statis Ke Anarkis. ed. LKiS Yogyakarta. Yogyakarta.

Mustaqim, Abdul. 2015. Metode Penelitian Al-Qur'an Dan Tafsir. Yogyakarta: Idea Press.

Najati, Muhammad 'Utsman. 2008. The Ultimate Psychology: Psikologi Sempurna Ala Nabi. Bandung: Pustaka Hidayah.

Nugroho, Muhammad Aji. 2016. "Hermeneutika Al-Qur'an Hasan Hanafi : Merefleksikan Teks Pada Realitas Sosial Dalam Konteks Kekinian." Millati: Journal of Islamic Studies and Humanities 1(2).

Parani, Rizaldi dkk. 2018. "Mempertanyakan Kembali Bhineka Tunggal Ika Di Era Post-Truth Melalui Media Sosial." Lontar 6(2).

RI, Lajnah Pentashihan Mushaf Al-Qur'an Balitbang dan Diklat Kementrian Agama. 2019. Tafsir Maudu'i (Tafsir Al-Qur'an Tematik). Jakarta: PT Lentera Ilmu Makrifat.

Shihab, M. Quraish. 1995. Membumikan Al-Qur'an: Fungsi Dan Peran Wahyu Dalam Kehidupan Masyarakat. Bandung: Mizan.

—. 2003a. Tafsir Al-Misbah: Pesan, Kesan Dan Keserasian Al-Qur'an. 14th ed. Jakarta: Lentera Hati. 
2003b. Tafsir Al-Misbah: Pesan, Kesan Dan Keserasian Al-Qur'an. 15th ed. Jakarta: Lentera Hati. 